\title{
The Semaphorin Receptor PlexinA3 Mediates Neuronal Apoptosis during Dorsal Root Ganglia Development
}

\author{
Ayal Ben-Zvi, ${ }^{1}$ Osnat Manor, ${ }^{1}$ Melitta Schachner, ${ }^{2}$ Avraham Yaron, ${ }^{3}$ Marc Tessier-Lavigne, ${ }^{4}$ and Oded Behar ${ }^{1}$ \\ ${ }^{1}$ The Hubert H. Humphrey Center for Experimental Medicine and Cancer Research, The Hebrew University Faculty of Medicine, Jerusalem 91120, Israel, \\ ${ }^{2}$ Zentrum fuer Molekulare Neurobiologie, Universitaetskrankenhaus Eppendorf, D-20251 Hamburg, Germany, ${ }^{3}$ Biological Chemistry, Weizmann Institute \\ of Science, Rehovot 76100, Israel, and ${ }^{4}$ Genentech, Inc., South San Francisco, California 94080-4990
}

Extensive neuronal cell death during development is believed to be due to a limiting supply of neurotrophic factors. In vitro studies suggest that axon guidance molecules directly regulate neuronal survival, raising the possibility that they play a direct role in neuronal cell death in vivo. However, guidance errors may also influence survival indirectly due to loss of target-derived neurotrophic support. The role of guidance molecules in neuronal death in vivo has thus been difficult to decipher. Semaphorin $3 \mathrm{~A}$, a repulsive guidance cue for sensory neurons, can induce sensory neuron death in vitro. Null mice studies of the Semaphorin3A coreceptors showed that guidance activity is mediated by PlexinA4, but PlexinA3 partially compensates in PlexinA4 ${ }^{-1-}$ mice. Here we demonstrate that both Plexins contribute to Sema3A-induced cell death in vitro, albeit in a different hierarchy. PlexinA3 is absolutely required, while PlexinA4 makes a smaller contribution to cell death. We found that PlexinA $3^{-1-}$ mice, which, unlike PlexinA4 ${ }^{-1-}$ mice, do not exhibit sensory axon patterning defects, show reduced neuronal apoptosis and an increased number of DRG neurons. Semaphorin3A involvement in neuronal death in vivo was demonstrated by a sensitization experiment using the proapoptotic effector Bax. Our results identify Plexins as mediators of Semaphorin-induced cell death in vitro, and provide the first evidence implicating Semaphorin/Plexin signaling in neuronal survival independent of its role in axon guidance. The results also support the idea that naturally occurring neuronal cell death reflects not only competition for target-derived trophic factors, but also the action of proapoptotic signaling via a Semaphorin/Plexin pathway.

Key words: DRG neurons; cell death; sensory neurons; apoptosis; embryo; survival

\section{Introduction}

The vertebrate nervous system undergoes massive cell death during development, with a loss of approximately half the neurons (Oppenheim, 1991). Current theories suggest that limited trophic support at the target field reduces the number of neurons to the level needed for appropriate innervation (Burek and Oppenheim, 1996). However, apoptosis of neurons, like those in dorsal root ganglia (DRG), occurs at early stages of development, when many neurons are still growing to their target fields (Coggeshall et al., 1994; White et al., 1996).

While extending axons to their target, neurons encounter guidance molecules present in surrounding tissues (Huber et al., 2003). Accumulating evidence from in vitro experiments indicates that neuronal apoptosis can result not just from removal of neurotrophic support, but also in response to guidance molecules such as Semaphorin3A (Sema3A) (Gagliardini and Fankhauser, 1999; Shirvan et al., 1999). However, whether Sema-

\footnotetext{
Received July 30, 2008; revised Sept. 22, 2008; accepted 0ct. 6, 2008.

This work was supported by an Israel Science Foundation Grant (350/07). We thank Dr. Y. Groner for generously supplying antibody against RUNX-3 and Dr. L. F. Reichardt for generously providing polyclonal antibodies against TrkA. We thank Dr. Norman Grover (Hebrew University, Jerusalem, Israel) for his helpful advice regarding the statistical analyses. We also thank Dr. Ze'ev Paroush for valuable comments on this manuscript.

Correspondence should be addressed to Oded Behar at the above address. E-mail: odedb@ekmd.huji.ac.il. DOI:10.1523/JNEUROSCI.3573-08.2008

Copyright $\odot 2008$ Society for Neuroscience $\quad$ 0270-6474/08/2812427-06\$15.00/0
}

phorins are also involved in neuronal apoptosis in vivo is not known.

The receptor for Sema3A comprises a receptor-binding subunit, Neuropilin1 (NP1), in complex with members of the Plexin family (Nakamura et al., 2000). Experiments using knock-out mice indicate that PlexinA4 is important for the axon-repellent activity of Sema3A, but in its absence PlexinA 3 can largely replace its function (Suto et al., 2005; Yaron et al., 2005). PlexinA3 plays a much more important role in Sema3A-induced pruning of hippocampal axons (Bagri et al., 2003). The cell adhesion molecule L1, which directly associates with NP1, is also necessary for Sema3A-mediated repulsion in vitro (Castellani et al., 2000). These data suggest that different biological functions of Sema3A are mediated by different members of the PlexinA subfamily. Which receptor components are involved in Sema3A-induced cell death, however, is unknown.

\section{Materials and Methods}

Antibodies, growth factors and materials. NGF was obtained from Sigma, human recombinant neurotrophin-3 (NT-3) and brain-derived neurotrophic factor (BDNF) were obtained from Alomone Laboratories, anticleaved caspase-3 and anti-TrkB were from Cell Signaling Technology, anti-RUNX-3 was a kind gift from Y. Groner (Weizmann Institute of Science, Rehovot, Israel), anti-TrkA RTA was a kind gift from L. Reichardt (University of California, San Francisco, San Francisco, CA), anti-Islet-1 40.2D6 (developed by Thomas M. Jesell, Columbia University, New York, NY) was from the Hybridoma Bank University of Iowa, 
Iowa City, IA. Secondary antibodies were obtained from Jackson Immunoresearch Laboratories. Tissue culture reagents were purchased from Biological Industries. All other reagents were purchased from Sigma.

Preparation of Semaphorins. HEK293T cells were transfected with expression vectors for Sema3A, 3B, 3E, 3D, 3G and 6A. Conditioned media from transfected cells were partially purified using a 30,000 MWCO (Amicon). Semaphorin concentrations was evaluated by Western blotting.

Animals. Pregnant mice were obtained following overnight mating (day of vaginal plug is defined as embryonic day 0.5). Mutant mice were obtained and genotyped as previously described [PlexinA3 (Cheng et al., 2001), A4 (Yaron et al., 2005), L1cam (Dahme et al., 1997) and Sema3A null mice (Behar et al., 1996)]. BAX-null mutant mice (Knudson et al., 1995) were obtained from Jackson Laboratory. In all experiments, a heterozygous breeding strategy was used to obtain both wild-type and mutant embryos in each experiment. Animal handling adhered strictly to national and institutional guidelines for animal research and was approved by the Ethics Committee of the Hebrew University.

Immunohistochemistry. Embryos were fixed, cryosectioned and immunostained as previously described (Lerman et al., 2007).

In vitro cell survival assays. Analysis was performed as previously described (Ben-Zvi et al., 2006).

In vivo analysis. We examined the lumbar DRG level, collecting every third section to alternating slides. All observations reported are based on analysis of multiple tissue sections (at least 25 per embryo) from three-six embryos of each genotype tested. In all methods the cells were counted by an observer who was blind to the genotype of the embryos tested. Three methods were used to evaluate the level of cell death:

TUNEL analysis. Staining was performed using the DeadEnd Fluorometric TUNEL System (Promega) according to the manufacturer's instructions. Fluorescent cells were counted and the mean number of TUNEL-positive cells per section area was determined.

Quantification of cells expressing activated caspase-3. Sections were costained with anti-cleaved caspase-3/antineurofilament. The number of cleaved caspase-3-positive cells per section was counted (section areas were measured using the ImageJ program and the average section area defined as 1 . All counting was corrected according to the section area).

Sections were costained with anti-cleaved caspase-3/anti-Islet- 1 antibodies. In each section, one area of the DRG was selected randomly. Both cleaved caspase-3- and Islet-1-positive neurons were counted. In each such field, the percentage of activated caspase-3-positive cells per total number of Islet-1-positive neurons was calculated (25 fields/DRG).

Neuronal cell counts. Serial cryosections $(15 \mu \mathrm{m})$ of the first lumbar DRGs were collected and stained with anti-Islet-1 antibody. Each cryosection was analyzed in $5 \mu \mathrm{m}$ optical sections using confocal microscopy. Cells were counted manually in one of every three optical sections (middle section) throughout $30-40$ cryosections which cover the entire DRG (four different DRGs from three embryos of each genotype were analyzed). Neuron numbers were estimated essentially as described previously (Patel et al., 2000).

Neuronal cell population counts. One in every fourth section of the first lumbar DRGs was stained with Islet-1/TrkA, Islet-1/TrkB, Islet-1/ RUNX3 or Islet-1, and with all three antibodies together, and then photographed and analyzed as in the neuronal cell count method. At least 40 sections for each antibody combination (10 sections/DRG) were counted, covering one quarter of four different DRGs from three embryos of each genotype.

\section{Results}

\section{PlexinA3 is the key receptor subunit responsible for Sema3A-} induced cell death

Semaphorin family members such as Sema3A and 3F can induce death of different cell types, including neurons (Gagliardini and Fankhauser, 1999; Castro-Rivera et al., 2004; Guttmann-Raviv et al., 2007). The best characterized case for such activity is the Sema3A-induced death of embryonic sensory neurons, which show characteristics of apoptosis (Gagliardini and Fankhauser, 1999; Ben-Zvi et al., 2006). We studied this effect using
PlexinA $3^{-/-}$, PlexinA4 $4^{-/-}$and $\mathrm{L}^{-/-}$mice to identify receptor components involved in semaphorin-induced cell death. For this, Sema3A-induced death was tested in the absence of each receptor component. E12.5 DRG neurons were incubated for $24 \mathrm{~h}$ with NGF and Sema3A (0 or $100 \mathrm{pm}$ ) (Fig. $1 A, B$ ). The maximal reduction in cell survival of wild-type neurons in response to Sema3A was defined as a 100\% killing effect. The killing effect (\%) in mutant embryos, normalized to wild-type neurons, was then calculated (detailed results on cell survival are also provided in supplemental Fig. 1, available at www.jneurosci.org as supplemental material). $\mathrm{L}^{-1-}$ neurons are as sensitive to Sema3A-induced death as wild-type neurons ( $p=0.82, \chi^{2}$ test) (Fig. $1 B$ ). In contrast, PlexinA $3^{-I-}$ neurons are totally resistant to Sema3A-induced cell death, indicating that this protein is absolutely required for Sema3A-induced death in vitro (Fig. 1B). The difference in survival with or without Sema3A in PlexinA $3^{-1-}$ neurons is not significant $\left(p=0.15, \chi^{2}\right.$ test $)$. PlexinA $4^{-1-}$ neurons are also less sensitive to Sema3A-induced death $(46 \pm 10 \%$ SEM) (Fig. $1 B)$. The difference in survival with or without Sema3A in PlexinA4 ${ }^{-l-}$ neurons is significant $(p<$ $10^{-5}, \chi^{2}$ test).

NT-3-dependent DRG neurons from PlexinA $3^{-1-}$ were also resistant to Sema3A-induced death (Fig. $1 B$ ); the difference in survival with or without Sema3A in PlexinA3 ${ }^{-1-}$ neurons is not significant ( $p=0.6, \chi^{2}$ test). In contrast, BDNF-dependent PlexinA $3^{-1-}$ neurons were not protected from Sema3A-induced cell death at this developmental stage. Thus, PlexinA3 is critical for Sema3A-induced cell death in both NT-3- and NGFdependent neurons. However, a small minority of PlexinA3 ${ }^{-1-}$ neurons (BDNF-dependent) is not protected, possibly because another Plexin mediates cell death in this subpopulation.

\section{Cell death following neurotrophin withdrawal in the absence of PlexinA3}

Developing neurons die unless sufficient amounts of neurotrophins are present (Silos-Santiago et al., 1995). In theory, neurotrophins may prevent death by suppressing death-inducing molecules such as Sema3A. We therefore examined the expression of Sema3A mRNA in these cultures by RT-PCR. Sema3A mRNA levels were not affected by neurotrophin withdrawal (data not shown). To test the sensitivity of DRG neurons to neurotrophin withdrawal, neurons from PlexinA $3^{-/-}$and PlexinA $3^{+/+}$littermates were monitored for a period of $24 \mathrm{~h}$ (NGF) or $48 \mathrm{~h}$ (NT-3) following neurotrophin removal (Fig. 1D). Cell death in PlexinA $3^{-1-}$ neurons (NGF and NT-3 cultures) was slower compared with PlexinA3 ${ }^{+/+}$neurons.

\section{Reduction in DRG cell death in the absence of PlexinA3}

To test the role of Semaphorin/Plexin signaling in vivo, we began our analysis with PlexinA3 ${ }^{-1-}$ mice since PlexinA3 is absolutely required for cell death, while axon guidance errors are not found in these mice (in contrast to Sema $3 \mathrm{~A}^{-/-}$and Plexin $4^{-/-}$mice). Levels of apoptosis were analyzed (using activated caspase-3) in lumbar DRG sections prepared from PlexinA $3^{-/-}$and wild-type littermates (Fig. 2A-D). The percentage of cleaved caspase-3positive/Islet-1-positive neurons, a postmitotic neuronal marker (Avivi and Goldstein, 1999), in the same microscopic fields were determined (Fig. $2 A, B$ ). In wild-type embryos at E12.5 we detected $40.87 \pm 4.1 \%$ positive cells, while in PlexinA $3^{-/-}$embryos we detected only $24.81 \pm 7.3 \%$. At E13.5 in wild-type embryos we detected $13.6 \pm 1.1 \%$, while in PlexinA $3^{-1-}$ embryos we detected only $7.6 \pm 1.8 \%$. Finally, at E15.5, the percentage of cell death was similar (wild-type, $10.1 \pm 1.3 \%$; PlexinA $3^{-1-}, 10.5 \pm 3.3 \%$ ). The 

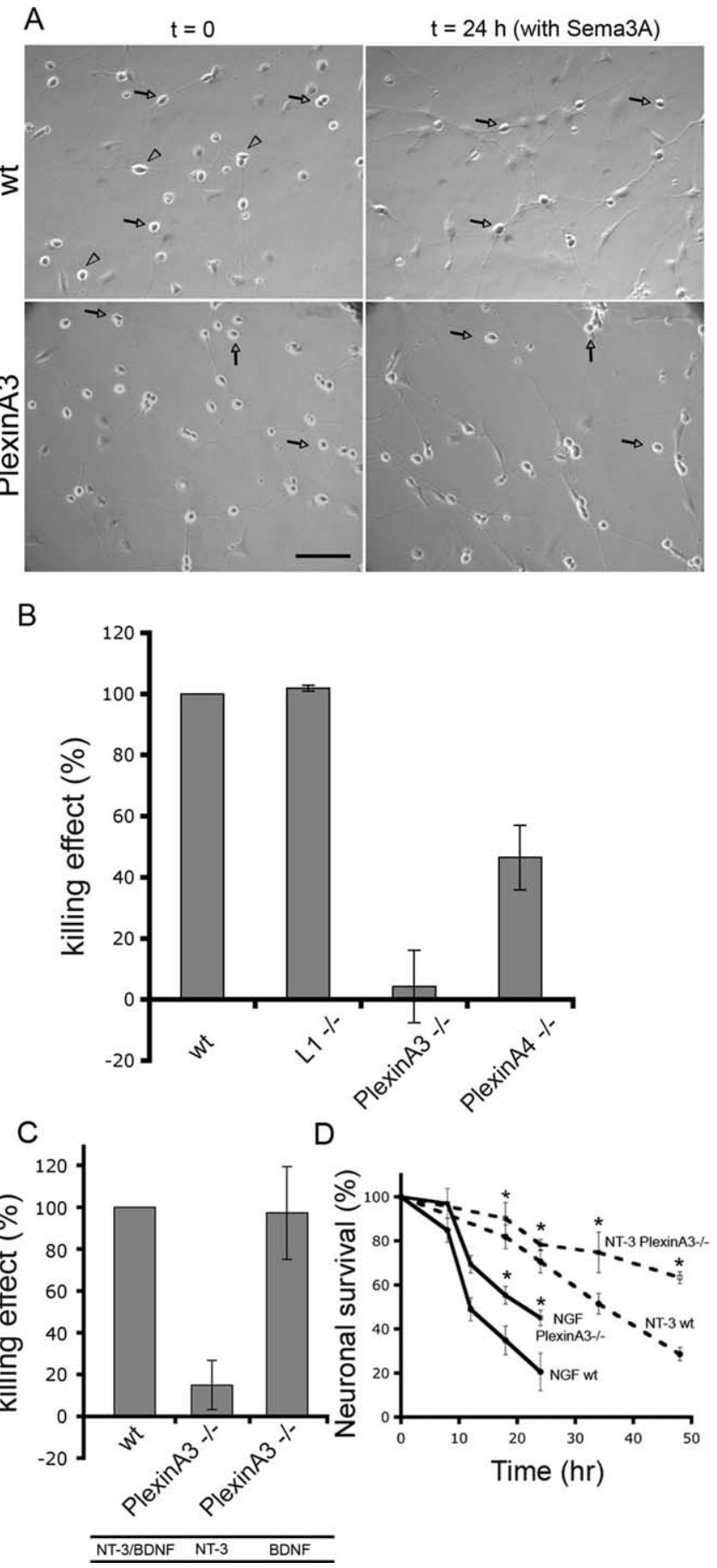

Figure 1. PlexinA3 is the key receptor subunit responsible for Sema3A-induced cell death. Survival effects of Sema3A on NGF-dependent neuronal cultures prepared from $\mathrm{L}^{-1-}$, PlexinA $3^{-1-}$, or PlexinA4 ${ }^{-1-}$ mice. Neurons from wild-type littermates were prepared for each mutant line. In each experiment, neurons were grown for $16 \mathrm{~h}$ and then re-fed $(t=0)$ with fresh medium in the presence or absence of $100 \mathrm{pm}$ Sema3A. The same fields were counted at $t=0$, and $t=24 \mathrm{~h}$. $A$, Representative cultures of wild-type (top) or PlexinA $3^{-1-}$ (bottom) neurons are shown at time $=0$ and $24 \mathrm{~h}$ of the same field. Note the changes in the neurite network in PlexinA $3^{-1-}$ neuronal cultures because of additional Sema3A functions that are not related to its cell death activity and are not blocked in the absence of this receptor component. Arrows indicate examples of surviving neurons and arrowheads marks examples of neurons at $t=0 \mathrm{~h}$ that are no longer present at $t=24 \mathrm{~h}$. $\boldsymbol{B}$, Sema3A-induced reduction in cell survival of wild-type neurons (for each experiment) was defined as a $100 \%$ killing-effect. The killing-effect (\%) in mutant embryos normalized to wild-type neurons is presented for each mouse line (C) NT-3- and BDNF-dependent neuronal cultures were prepared from PlexinA $3^{-/-}$and wild-type littermates, and the killing-effect (\%) of Sema3A was calculated as in $\boldsymbol{B}$. D. Survival of neurons (PlexinA $3^{-/-}$and wild-type littermates) following neurotrophin differences between wild-type and PlexinA $3^{-1-}$ DRG neurons both at E12.5 and E13.5 are significant $\left(p<10^{-5}, \chi^{2}\right.$ test).

As an alternative method for evaluating neuronal death, we also counted the number of cleaved caspase-3-positive cells per section area. At E12.5, we detected an average of $44.6 \pm 3$ cleaved caspase-3-positive cells/section area in wild-type embryos, and only $24.3 \pm 2.7$ cells/section area in PlexinA $3^{-1-}$ embryos. At E13.5 a reduction in cell death in PlexinA $3^{-1-}$ mutants is also observed $(18.3 \pm 2.1$ cells/section in wild-type embryos, versus $9.5 \pm 1.9$ cells/section area in PlexinA $3^{-1-}$ embryos. At E15.5 the levels of cell death are low in both wild-type $(11.7 \pm 1.5$ cells/ section area) and PlexinA $3^{-1-}$ mice $(6.9 .9 \pm 0.8$ cells/section area). The differences between wild-type and Plexin $\mathrm{A} 3^{-1-}$ mice both at E12.5 and E13.5 are significant (at E12.5 $p=0.016$, as determined by a one-tailed Wilcoxon test with six wild-type and six PlexinA3 mutant embryos, and at E13.5 $p=0.05$, as determined by a one-tailed Mann-Whitney U test with three wild-type and three PlexinA $3^{-l-}$ embryos).

We further tested cell death using the TUNEL assay. We detected $41.8 \pm 3$ cells/section area in wild-type embryos versus $20.4 \pm 3$ cells/section area in PlexinA3 ${ }^{-1-}$ embryos. The difference between wild-type and PlexinA $3^{-1-}$ mutants is significant ( $p=0.05$, as determined by a one-tailed Mann-Whitney $\mathrm{U}$ test with three wild-type and three PlexinA $3^{-1-}$ embryos). We therefore conclude that the absence of PlexinA3 leads to a reduction of up to $50 \%$ in cell death in the developing DRG.

We also tested the levels of activated caspase- 3 in sections of lumbar DRGs prepared from PlexinA4 ${ }^{-1-}$ embryos and wildtype littermates (data not shown). No significant difference was observed between PlexinA $4^{-1-}$ and wild-type littermates.

\section{Increase in DRG neuron numbers in PlexinA3 ${ }^{-/-}$mice}

To investigate whether reduction in cell death in PlexinA $3^{-/-}$ DRG at E12.5-13.5 results in supernumerary neurons, we counted the number of neurons in the first lumbar DRGs at E15.5. In PlexinA $3^{-1-}$ embryos, the average number of neurons is $6914 \pm 178$, while in wild-type littermates it is $5896 \pm 445$, a significant increase of $\sim 17 \%$ in the total number of neurons ( $p=0.05$, one-tailed Mann-Whitney $\mathrm{U}$ test). By analyzing sequential sections with TrkA/Islet-1, TrkB/Islet-1 or Runx3/ Islet-1 markers (RUNX3 is a marker for TrkC-positive neurons), or using a mixture of three rabbit antibodies (anti-TrkA, antiTrkB, and anti-RUNX3) in conjunction with anti-Islet-1 (mouse), we found no change in the ratio of each population between PlexinA $3^{-1-}$ and wild-type littermates (Fig. $2 F, G, H$ ); however, the number of neurons which are both TrkA/TrkB/ RUNX-3-negative and Islet-1-positive in PlexinA $3^{-1-}$ mice is significantly higher compared with wild-type littermates $(p<$ $10^{-3}, \chi^{2}$ test). In addition, it is likely that some of the rescued cells are Trk-positive, but that the number of these cells is proportionally increased in all subpopulations.

\section{$\leftarrow$}

withdrawal (NGF-and NT-3-dependent neuronal cultures) was tested. Neurons were grown for $16 \mathrm{~h}$ before the medium was washed and replaced $(t=0)$ with fresh medium with or without neurotrophins. The same fields were counted at each time point. The percentage of surviving neurons in neurotrophin withdrawal experiments is normalized at each time point to percentage of neuronal survival in cultures with neurotrophins. Differences between wild-type and PlexinA $3^{-I-}$ neurons are significant ${ }^{*} p<0.014, \chi^{2}$ test). In all experiments, results represents mean \pm SEM of three independent experiments. Scale bar, $100 \mu \mathrm{m}$. 
A genetic sensitization experiment using $\mathrm{BAX}^{+/-}$mice reveals the involvement of Sema3A-induced cell death in developing DRG neurons

PlexinA3 was shown to mediate the signaling of at least two class-3 Semaphorins, Sema3A and Sema3F, and likely mediates signaling of other transmembrane Semaphorins. Sensory neurons lack the Sema3F binding unit (Neuropilin2), so Sema3A is a stronger candidate for activating PlexinA3 in these neurons. To test whether Sema3A also affects neuronal cell death in vivo we monitored sections from Sema3 $\mathrm{A}^{-1-}$ and Sema3 $\mathrm{A}^{+/+}$littermates. No significant differences were detected in either TUNEL or cleaved caspase- 3 assays (data not shown), suggesting that if Sema3A is involved in vivo, it is one of several redundant cues. To evaluate the ability of other Semaphorins to induce DRG neuronal cell death we tested Sema3B, 3E, 3D, $3 \mathrm{G}$ or $6 \mathrm{~A}$. Our results show that both Sema3B and Sema6A can induce cell death and may thus compensate for Sema3A function (supplemental Fig. 2, available at www.jneurosci.org as supplemental material).

Neuronal apoptosis is a polygenic trait, affected by several genes. To elucidate the contribution of Sema3A to this process we used a $\mathrm{Bax}^{+/-}$background to sensitize the system since DRG neuronal cell death is highly dependent on BAX activity (White et al., 1998; Lentz et al., 1999). Bax ${ }^{+/-}$retinal ganglion neurons are partly protected from cell death in vivo (Libby et al., 2005). Although effects of BAX ${ }^{+/-}$on DRG neuronal cell death in vivo have not been reported, we hypothesized that $\mathrm{BAX}^{+/-}$affects death signaling in this system as well. We therefore monitored the degree of cell death levels at E12.5 lumbar DRG from Sema3A, BAX littermates (Fig. 3). In both Sema $3 \mathrm{~A}^{+/+} ; \mathrm{BAX}^{+/+}$and Sema3A ${ }^{-1-}$; $\mathrm{BAX}^{+/+}$embryos we detected similar lev-

els of cleaved caspase- $3(35.5 \pm 5$ and $32.9 \pm 6$ cells/section, respectively). In Sema $3 \mathrm{~A}^{+/+} ; \mathrm{BAX}^{+/-}$embryos we detected an average of $12.3 \pm 3.7$ cells/section. Finally, we detected only $6.9 \pm$ 1.5 cells/section in Sema3 $\mathrm{A}^{-/-} ; \mathrm{BAX}^{+/-}$mutant embryos. Based on these results we conclude that the absence of Sema3A in conjunction with the loss of one allele of BAX leads to a reduction in cell death of $\sim 44 \%$ (compared with Sema3A ${ }^{+/+}$; $\mathrm{BAX}^{+/-}$ embryos).

\section{Discussion}

Accumulating evidence indicates that secreted Semaphorins can induce cell death of neuronal and non-neuronal cell populations (for example, see Gagliardini and Fankhauser, 1999; CastroRivera et al., 2004; Guttmann-Raviv et al., 2007). However, the relevance of this activity in vivo and the receptors that might be involved are not known. Here, we implicate Plexins in mediating the Semaphorin response by showing that PlexinA3 is required
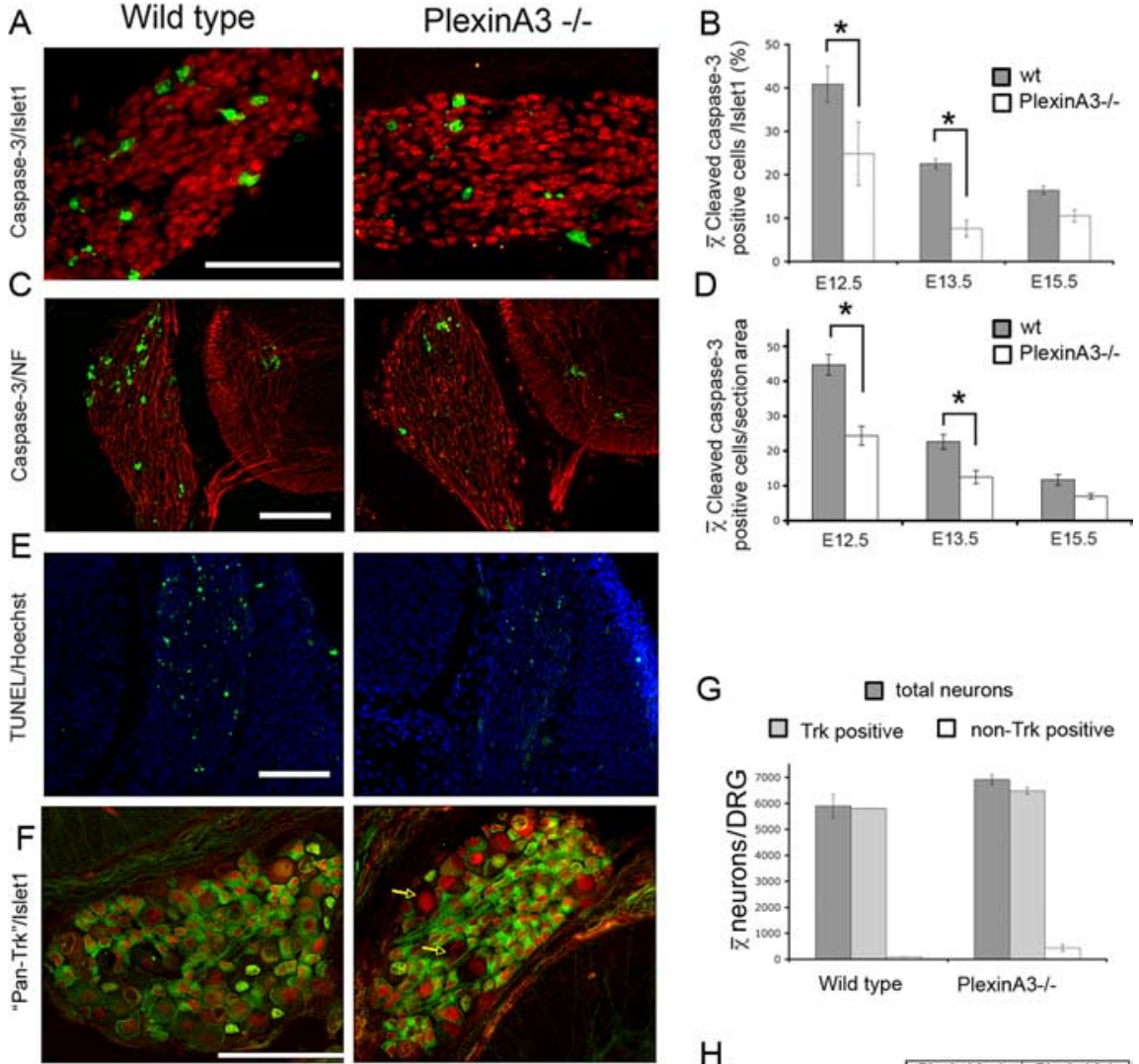

G
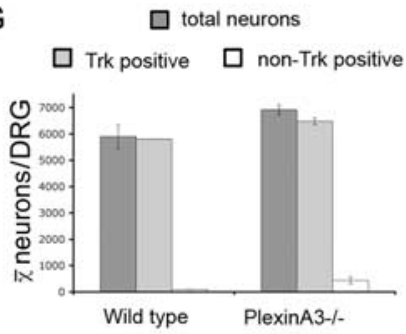

$\mathrm{H}$

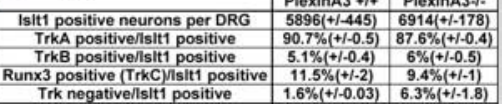

Figure 2. Loss of PlexinA3 results in a reduction in DRG cell death in vivo. E12.5, E13.5 and E15.5 embryos (PlexinA3 ${ }^{-1-}$ and E13.5 wild-type and PlexinA3 ${ }^{-1-}$ embryos are shown. $B$, Quantification of the average cleaved caspase-3-positive cells/

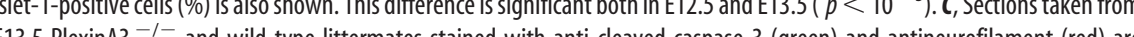
shown, together with their quantification $(\boldsymbol{D})$. The average number of cleaved caspase-3-positive cells/section area in PlexinA3 mutants is significantly lower (E12.5 $p=0.016, \mathrm{E} 13.5 p=0.05)$ than in wild-type littermates. $E$, TUNEL assay of E12.5 lumbar sections from PlexinA $3^{-/-}$and PlexinA $3^{+/+}$littermates. TUNEL-positive cells are labeled in green. Nuclei are labeled with eurons. $\boldsymbol{G}, \boldsymbol{H}$, Total number of neurons and percentage of each subpopulation (TrkA, TrkB or RUNX3) are shown. (For reasons of clarity, the Trk-negative and Trk-positive percentages in $\mathbf{G}$ were translated into numbers using the total neuronal number counts.) Results represent mean \pm SEM. Scale bars, $100 \mu \mathrm{m}$.

for neuronal cell death in vivo. This result provides the first evidence that Semaphorin receptor PlexinA3-mediated death in vitro is relevant in vivo, and also provides the first, albeit indirect, evidence for the involvement of Sema3A in cell death in vivo. Interestingly, our results also demonstrate that different functions of Semaphorins (death vs guidance) in the same neurons are differentially dependent on distinct receptor complexes, with PlexinA4 dominating in guidance and PlexinA3 in death (at least in the neurons studied here).

Semaphorin/PlexinA3 signaling effects on DRG neuronal cell death during development

Our in vitro experiments show that, in contrast to repulsion, PlexinA3 (but not L1 or PlexinA4) is absolutely required for Sema3A-induced cell death. Since in PlexinA3 ${ }^{-1-}$ mice the guidance of sensory neurons is normal, it was possible to test the involvement of Semaphorin/Plexin in death signaling without 


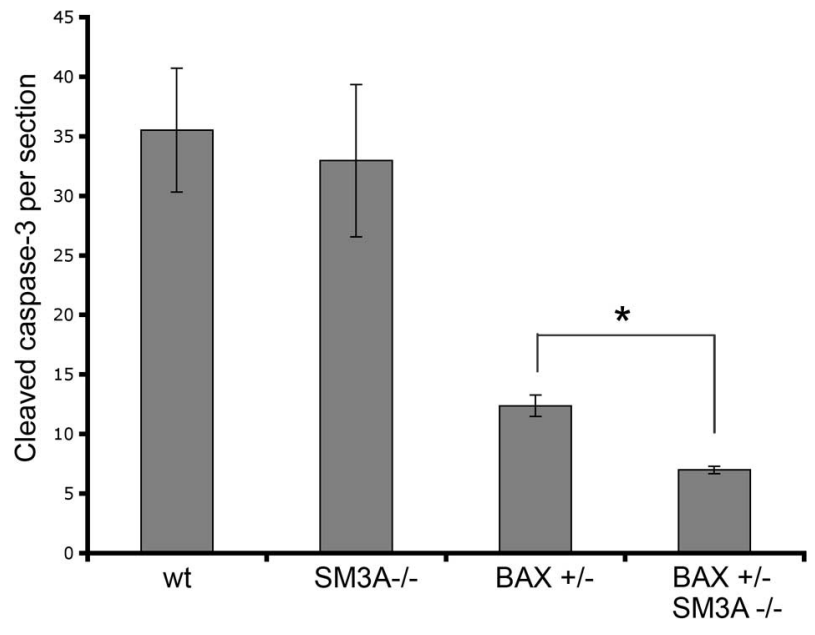

Figure 3. Genetic sensitization experiment using $B A X^{+/-}$reveals the involvement of Sema3A-induced death in the developing DRG. E12.5 embryos (Sema3A ${ }^{-1-} ; B A X^{+1-}$, Sema $3 \mathrm{~A}^{-1-} ; \mathrm{BAX}^{+/+}, \mathrm{Sema}_{3} \mathrm{~A}^{+/+} \mathrm{BAX}{ }^{+/-}$, and Sema $3 \mathrm{~A}^{+/+} ; \mathrm{BAX}^{+/+}$littermates) were fixed and sectioned. Quantification of cleaved caspase-3-positive cells is shown. The number of cleaved caspase-3-positive cells in Sema3 $\mathrm{A}^{-/-}$that are also heterozygous for BAX gene is significantly lower that $B A X^{+/-}$only embryos ( $p=0.034$, Mann-Whitney U test).

affecting axon guidance, which may indirectly affect neuronal death. Indeed, there is a significant reduction in apoptosis in PlexinA $3^{-1-}$ mice, albeit with a somewhat milder increase in neuronal numbers than would be expected from the degree of reduction of apoptosis. Interestingly, robust reduction of apoptosis with a milder increase in neuron numbers is also found in other mutant mice, such as in the case of $\mathrm{BAX}^{-1-}$ (White et al., 1998; Patel et al., 2000) or UNC5A ${ }^{-1-}$ (Williams et al., 2006) mutants, and may reflect the induction of compensatory nonapoptotic cell death mechanisms. The role of Sema3A as a death inducer in vivo is more complicated to evaluate. We found no significant difference in cell death in these mice. In addition to its putative role as a death molecule, Sema3A acts as a guidance molecule, and in its absence, there are numerous misguided sensory axons. This may result in deprivation of these neurons of their necessary trophic support, with a subsequent increase in neuronal death. Thus, the net result in Sema3 $\mathrm{A}^{-1-}$ mice may represent these two opposing factors: (1) reduced cell death as a result of the absence of Sema3A as a death molecule; (2) guidance errors that may increase cell death because some neurons are not innervating their appropriate targets. By analyzing neurons from $\mathrm{BAX}^{+/-}$mice, apoptotic signals are partly suppressed, and under these conditions we found that Sema3A clearly contributes to the apoptosis of DRG neurons in vivo. Our results thus suggest that Sema3A functions as a cell death molecule in vivo. It is also possible, however, that the absence of effect of Sema3A removal alone reflects the involvement of other Semaphorins that can act via PlexinA3. Future studies will be needed to determine the full complement of Semaphorins involved in cell death in vivo. Finally, the role PlexinA4 in cell death is difficult to evaluate. Although we did not find a decrease in cell death in PlexinA4 ${ }^{-/-}$ mice, guidance errors are found in these mice, making the results difficult to interpret since, as discussed, misrouting may enhance cell death and offset a reduction caused by loss of the receptor.

\section{Cell death in the nervous system: a balance between survival and death-inducing molecules}

Primary neurons undergo programmed cell death in the absence of appropriate trophic molecules (Silos-Santiago et al., 1995), while over-expression results in reduced neuronal death and an increase in neuronal number (Henderson, 1996). Thus, it is generally accepted that a limited amount of trophic support determines the number of surviving neurons (Oppenheim, 1991).

DRG apoptosis peaks around embryonic stage E12-E14 (White et al., 1996, 1998). At this stage, Sema3A is highly expressed and its expression has been shown to correlate with the growth of DRG axons toward their peripheral and central targets (Wright et al., 1995; Giger et al., 1996). Neurons prepared from DRG at this stage die when treated with Sema3A, but death is blocked by high levels of NGF (Ben-Zvi et al., 2006). Death by Sema3A is likely mediated by retrograde signaling (Gagliardini and Fankhauser, 1999). In this study we show that cell death as a result of neurotrophin withdrawal is reduced in PlexinA $3^{-1-}$ neurons. Thus, our results imply that neuronal death in the absence of neurotrophins may result at least in part because death signals are no longer suppressed. Our findings in vivo further show that the number of surviving neurons is not simply a result of limiting amounts of neurotrophins since similar amounts can support more neurons in the absence of PlexinA3. However, since apoptosis is still found in PlexinA $3^{-1-}$ DRG neurons, this could suggest the operation of either an additional deathinducing pathway or limited trophic support. Thus, it is apparent that some neurons are dying as a result of death signals mediated by the PlexinA3 receptor. We propose that at least in the case of developing DRG neurons, the classical trophic hypothesis needs to be modified to include a more complex model in which the number of surviving neurons represents a balance between survival and death-inducing molecules.

The possibility that this balance theory may represent a general phenomenon is supported by a recent study in spinal cord neurons. In this study it was found that death of embryonic motor neurons in UNC5A (a netrin receptor) ${ }^{-1-}$ mice is reduced in vivo (Williams et al., 2006). Although the ligand responsible for the activation of UNC5A is not known, this result is consistent with the possibility that a balance between survival and death signals also determines the number of motor neurons.

\section{References}

Avivi C, Goldstein RS (1999) Differential expression of Islet-1 in neural crest-derived ganglia: Islet-1 + dorsal root ganglion cells are post-mitotic and Islet-1 + sympathetic ganglion cells are still cycling. Brain Res Dev Brain Res 115:89-92.

Bagri A, Cheng HJ, Yaron A, Pleasure SJ, Tessier-Lavigne M (2003) Stereotyped pruning of long hippocampal axon branches triggered by retraction inducers of the semaphorin family. Cell 113:285-299.

Behar O, Golden JA, Mashimo H, Schoen FJ, Fishman MC (1996) Semaphorin III is needed for normal patterning and growth of nerves, bones and heart. Nature 383:525-528.

Ben-Zvi A, Yagil Z, Hagalili Y, Klein H, Lerman O, Behar O (2006) Semaphorin 3A and neurotrophins: a balance between apoptosis and survival signaling in embryonic DRG neurons. J Neurochem 96:585-597.

Burek MJ, Oppenheim RW (1996) Programmed cell death in the developing nervous system. Brain Pathol 6:427-446.

Castellani V, Chédotal A, Schachner M, Faivre-Sarrailh C, Rougon G (2000) Analysis of the L1-deficient mouse phenotype reveals cross-talk between Sema3A and L1 signaling pathways in axonal guidance. Neuron 27:237-249.

Castro-Rivera E, Ran S, Thorpe P, Minna JD (2004) Semaphorin 3B (SEMA3B) induces apoptosis in lung and breast cancer, whereas VEGF165 antagonizes this effect. Proc Natl Acad Sci USA 101:11432-11437.

Cheng HJ, Bagri A, Yaron A, Stein E, Pleasure SJ, Tessier-Lavigne M (2001) Plexin-A3 mediates semaphorin signaling and regulates the development of hippocampal axonal projections. Neuron 32:249-263.

Coggeshall RE, Pover CM, Fitzgerald M (1994) Dorsal root ganglion cell 
death and surviving cell numbers in relation to the development of sensory innervation in the rat hindlimb. Brain Res Dev Brain Res 82:193-212.

Dahme M, Bartsch U, Martini R, Anliker B, Schachner M, Mantei N (1997) Disruption of the mouse L1 gene leads to malformations of the nervous system. Nat Genet 17:346-349.

Gagliardini V, Fankhauser C (1999) Semaphorin III can induce death in sensory neurons. Mol Cell Neurosci 14:301-316.

Giger RJ, Wolfer DP, De Wit GM, Verhaagen J (1996) Anatomy of rat semaphorin III/collapsin-1 mRNA expression and relationship to developing nerve tracts during neuroembryogenesis. J Comp Neurol 375:378-392.

Guttmann-Raviv N, Shraga-Heled N, Varshavsky A, Guimaraes-Sternberg C, Kessler O, Neufeld G (2007) Semaphorin-3A and semaphorin-3F work together to repel endothelial cells and to inhibit their survival by induction of apoptosis. J Biol Chem 282:26294-26305.

Henderson CE (1996) Role of neurotrophic factors in neuronal development. Curr Opin Neurobiol 6:64-70.

Huber AB, Kolodkin AL, Ginty DD, Cloutier JF (2003) Signaling at the growth cone: ligand-receptor complexes and the control of axon growth and guidance. Annu Rev Neurosci 26:509-563.

Knudson CM, Tung KS, Tourtellotte WG, Brown GA, Korsmeyer SJ (1995) Bax-deficient mice with lymphoid hyperplasia and male germ cell death. Science 270:96-99.

Lentz SI, Knudson CM, Korsmeyer SJ, Snider WD (1999) Neurotrophins support the development of diverse sensory axon morphologies. J Neurosci 19:1038-1048.

Lerman O, Ben-Zvi A, Yagil Z, Behar O (2007) Semaphorin3A accelerates neuronal polarity in vitro and in its absence the orientation of DRG neuronal polarity in vivo is distorted. Mol Cell Neurosci 36:222-234.

Libby RT, Li Y, Savinova OV, Barter J, Smith RS, Nickells RW, John SW (2005) Susceptibility to neurodegeneration in a glaucoma is modified by Bax gene dosage. PLoS Genet 1:17-26.

Nakamura F, Kalb RG, Strittmatter SM (2000) Molecular basis of semaphorin-mediated axon guidance. J Neurobiol 44:219-229.
Oppenheim RW (1991) Cell death during development of the nervous system. Annu Rev Neurosci 14:453-501.

Patel TD, Jackman A, Rice FL, Kucera J, Snider WD (2000) Development of sensory neurons in the absence of NGF/TrkA signaling in vivo. Neuron 25:345-357.

Shirvan A, Ziv I, Fleminger G, Shina R, He Z, Brudo I, Melamed E, Barzilai A (1999) Semaphorins as mediators of neuronal apoptosis. J Neurochem 73:961-971.

Silos-Santiago I, Greenlund LJ, Johnson EM Jr, Snider WD (1995) Molecular genetics of neuronal survival. Curr Opin Neurobiol 5:42-49.

Suto F, Ito K, Uemura M, Shimizu M, Shinkawa Y, Sanbo M, Shinoda T, Tsuboi M, Takashima S, Yagi T, Fujisawa H (2005) Plexin-a4 mediates axon-repulsive activities of both secreted and transmembrane semaphorins and plays roles in nerve fiber guidance. J Neurosci 25:3628-3637.

White FA, Silos-Santiago I, Molliver DC, Nishimura M, Phillips H, Barbacid M, Snider WD (1996) Synchronous onset of NGF and TrkA survival dependence in developing dorsal root ganglia. J Neurosci 16:4662-4672.

White FA, Keller-Peck CR, Knudson CM, Korsmeyer SJ, Snider WD (1998) Widespread elimination of naturally occurring neuronal death in Baxdeficient mice. J Neurosci 18:1428-1439.

Williams ME, Lu X, McKenna WL, Washington R, Boyette A, Strickland P, Dillon A, Kaprielian Z, Tessier-Lavigne M, Hinck L (2006) UNC5A promotes neuronal apoptosis during spinal cord development independent of netrin-1. Nat Neurosci 9:996-998.

Wright DE, White FA, Gerfen RW, Silos-Santiago I, Snider WD (1995) The guidance molecule semaphorin III is expressed in regions of spinal cord and periphery avoided by growing sensory axons. J Comp Neurol 361:321-333.

Yaron A, Huang PH, Cheng HJ, Tessier-Lavigne M (2005) Differential requirement for Plexin-A3 and -A4 in mediating responses of sensory and sympathetic neurons to distinct class 3 Semaphorins. Neuron 45:513523 